\title{
UCRL-JRNL-226724
}

LAW RENCE LIVERMORE N A T IO N A L LABORATORY

Decadal- to interannual-scale source water variations in the Caribbean Sea recorded by Puerto Rican coral radiocarbon

K. H. Kilbourne, T. M. Quinn, T. P. Guilderson, R. S. Webb, F. W. Taylor

December 11, 2006

Climate Dynamics 
This document was prepared as an account of work sponsored by an agency of the United States Government. Neither the United States Government nor the University of California nor any of their employees, makes any warranty, express or implied, or assumes any legal liability or responsibility for the accuracy, completeness, or usefulness of any information, apparatus, product, or process disclosed, or represents that its use would not infringe privately owned rights. Reference herein to any specific commercial product, process, or service by trade name, trademark, manufacturer, or otherwise, does not necessarily constitute or imply its endorsement, recommendation, or favoring by the United States Government or the University of California. The views and opinions of authors expressed herein do not necessarily state or reflect those of the United States Government or the University of California, and shall not be used for advertising or product endorsement purposes. 


\section{Decadal- to interannual-scale source water variations in the Caribbean Sea recorded by Puerto Rican coral radiocarbon}

For submission to Climate Dynamics

K. Halimeda Kilbourne ${ }^{1,2}$, Terrence M. Quinn ${ }^{1,3}$, Thomas P. Guilderson ${ }^{4,5}$, Robert S. $\mathrm{Webb}^{2}$, and Frederick W. Taylor ${ }^{3}$

${ }^{1}$ College of Marine Science, University of South Florida, $1407^{\text {th }}$ Avenue South, St. Petersburg, FL 33707, USA

${ }^{2}$ NOAA, Earth System Research Laboratory,R/PSD1, 325 Broadway, Boulder, CO 80305

${ }^{3}$ Institute for Geophysics, The John A. and Katherine G. Jackson School of Geosciences, The Univ. of Texas at Austin, 4412 Spicewood Springs Road, Austin, TX 78759-8500, USA

${ }^{4}$ Center for Accelerator Mass Spectrometry, Lawrence Livermore National Laboratory, P.O. Box 808, L-397, Livermore, CA 94550, USA

${ }^{5}$ Also at the Department of Ocean Sciences and Institute of Marine Science, University of California at Santa Cruz, 1156 High Street, Santa Cruz, CA 95064

Communicating author K.H. Kilbourne: $\quad$ hali@marine.usf.edu

Fax: 727-553-1189 


\begin{abstract}
Water that forms the Florida Current, and eventually the Gulf Stream, coalesces in the Caribbean from both subtropical and equatorial sources. The equatorial sources are made up of, in part, South Atlantic water moving northward and compensating for southward flow at depth related to meridional overturning circulation. Subtropical surface water contains relatively high amounts of radiocarbon $\left({ }^{14} \mathrm{C}\right)$, whereas equatorial waters are influenced by the upwelling of low ${ }^{14} \mathrm{C}$ water and have relatively low concentrations of ${ }^{14} \mathrm{C}$. We use a 250 -year record of $\Delta^{14} \mathrm{C}$ in a coral from southwestern Puerto Rico along with previously published coral $\Delta^{14} \mathrm{C}$ records as tracers of subtropical and equatorial water mixing in the northern Caribbean. Data generated in this study and from other studies indicate that the influence of either of the two water masses can change considerably on interannual to interdecadal time scales. Variability due to ocean dynamics in this region is large relative to variability caused by atmospheric ${ }^{14} \mathrm{C}$ changes, thus masking the Suess effect at this site. A mixing model produced using coral $\Delta^{14} \mathrm{C}$ illustrates the time varying proportion of equatorial versus subtropical waters in the northern Caribbean between 1963 and 1983. The results of the model are consistent with linkages between multidecadal thermal variability in the North Atlantic and meridional overturning circulation. Ekman transport changes related to tradewind variability are proposed as a possible mechanism to explain the observed switches between relatively low and relatively high $\Delta^{14} \mathrm{C}$ values in the coral radiocarbon records.
\end{abstract}

\title{
INTRODUCTION
}

Sverdrup theory (Sverdrup 1947) predicts that a southward interior flow in the North Atlantic be compensated by an equal rate of northward flow at the western boundary. The return flow of meridional overturning circulation (MOC) theoretically moves northward in the western boundary current as well (Schmitz and Richardson 1991), so the total northward transport in the western boundary should equal the total of MOC plus the wind-driven transport. Water comprising much of the western boundary current along North America (Florida Current and Gulf Stream system) coalesces in the Caribbean Sea and exits the Caribbean Sea through the Yucatan Straits as a well-defined, rapidly moving western boundary current. Hydrographic surveys of the Caribbean inflow 
have found that the inflow to the Caribbean comes from 1) primarily South Atlantic origins (Wust 1964), ostensibly in part from MOC return flow, or 2) from primarily North Atlantic origins (Mazeika et al. 1983; Metcalf et al. 1971; Parr 1937), ostensibly driven by Sverdrup transport. These conflicting results lead Wilson and Johns (1997) to conclude that the amount of water coming into the Caribbean from the South and North Atlantic may be variable with time.

Recent attention to the possibility of abrupt climate change in the Northern Hemisphere driven by MOC shut-down (Broecker 1998; Ganopolski and Rahmstorf 2001), and the identification of multidecadal changes in surface ocean temperature anomalies (Schlesinger and Ramankutty 1994) which may be related to smaller changes in the MOC (Delworth and Mann 2000), elevates the importance of time-varying Caribbean source water. Continuity requires that increased (decreased) deep oceanic convection at high latitude be compensated by increased (decreased) return flow at the surface, which must come across the equator from the South Atlantic, in order to be transported northward. Thus, the first-order hypothesis is that time varying MOC strength should be related to the proportion of North Atlantic versus South Atlantic waters entering the Caribbean Sea, where much of the water making up the Gulf Stream originates.

Documenting the time-varying inflow to the Caribbean is difficult. Despite multiyear sampling efforts (e.g., Johns et al. 2002; Rhein et al. 2005), and many previous hydrographic surveys in the region, the Caribbean inflow is under sampled. What is needed is a multi-decadal record of water-mass tracers that integrates the high frequency variability such as eddies and tides, but resolves the interannual- to decadal-scale variability. Massive corals provide an ideal archive of such information because their skeletons record the $\Delta^{14} \mathrm{C}$ of the dissolved inorganic carbon (DIC) in the water as they grow, which can be used as a water-mass tracer (e.g., Druffel and Griffin 1993; Druffel and Linick 1978; Guilderson et al. 2004; Guilderson et al. 1998). These corals can be long-lived (centuries), and their skeletons have annual density bands, much like tree rings, which can be counted to provide excellent age control for the measured geochemical tracer time series. Additionally, coral skeletal material contains multiple 
independent records of environmental conditions, two of which are commonly used to reconstruct temperature $\left(\mathrm{Sr} / \mathrm{Ca}\right.$ and $\left.\delta^{18} \mathrm{O}\right)$ and salinity $\left(\delta^{18} \mathrm{O}\right)$.

We use a 250 -year long $\Delta^{14} \mathrm{C}$ record sampled at annual resolution from a coral growing off southwestern Puerto Rico to reconstruct surface water mass changes in the northern Caribbean. Combining our results with those of previous studies, we are able to identify a wide spread $\Delta{ }^{14} \mathrm{C}$ event in the circum-Caribbean region during the early $1950 \mathrm{~s}$, and create a 20-year time series of the proportion of equatorial versus subtropical waters influencing southwestern Puerto Rico.

\section{METHODS}

\section{Coral $\Delta^{14} C$ as a water mass tracer in the Caribbean}

Use of radiocarbon in seawater dissolved inorganic carbon as a water-mass tracer began with some of the first oceanic radiocarbon measurements in the 1950s (e.g., Broecker and Olson 1961), and coral $\Delta^{14} \mathrm{C}$ has been used as a water-mass tracer since the late 1970s (e.g., Druffel 1980, 1989; Druffel 2002; Druffel and Linick 1978; Guilderson et al. 2004; Guilderson et al. 1998). Corals ultimately utilize seawater DIC for the carbon in their skeletons, so coral skeletal $\Delta{ }^{14} \mathrm{C}$ can be a proxy for seawater $\Delta{ }^{14} \mathrm{C}$ after using $\delta^{13} \mathrm{C}$ to correct for the mass-dependent fractionation that occurs during calcification. Good agreement between radiocarbon measurements taken just off the southwestern coast of Puerto Rico as part of a World Ocean Circulation Experiment (WOCE) cruise in the summer of $1997(75.9 \pm 4.2 \%$ o $)$ and coeval coral $\Delta^{14} \mathrm{C}(81.0 \pm 3.3 \%$ ) provides further evidence for the fidelity of coral $\Delta^{14} \mathrm{C}$ to record isotopic ratios of seawater DIC. Only a few coral $\Delta{ }^{14} \mathrm{C}$ time series from the Atlantic are published, and they are from Brazil, Cape Verde, Venezuela, Belize, the Florida Keys, and Bermuda (Druffel 1980; Druffel 1982; Druffel 1989, 1996; Druffel 1997b; Guilderson et al. 2005).

The primary controls on surface ocean $\Delta^{14} \mathrm{C}$ are equilibration with the atmosphere, advection, diffusion, and convective mixing (Mahadevan 2001). Major water sampling programs such as the Geochemical Ocean Sections Study (GEOSECS) and WOCE, as well as the efforts of smaller groups document persistent features of the surface $\Delta^{14} \mathrm{C}$ in the Atlantic, illustrated in Figure 1. Water in the subtropical gyres has the highest $\Delta^{14} \mathrm{C}$ 
because of long residence times at the surface and high rates of gas exchange due to strong winds. In contrast, water in the equatorial regions is subject to vertical mixing with ${ }^{14} \mathrm{C}$-depleted water from depth through upwelling off the west coast of Africa, and therefore has consistently lower $\Delta^{14} \mathrm{C}$. The contrast between the North Atlantic gyre and the south equatorial region was $10 \%$ o before about 1957, when nuclear bomb-produced ${ }^{14} \mathrm{C}$ began to substantially affect the surface ocean (Table 1, Broecker and Olson 1961). The gradient has steepened since that time because the surface waters equilibrated with the bomb carbon spike in ${ }^{14} \mathrm{C}$, while the deeper waters being upwelled were essentially unaffected.

Southwestern Puerto Rico is an ideal site to monitor seawater $\Delta^{14} \mathrm{C}$. The prevailing northeasterly trade winds make the local circulation regime more prone to downwelling than upwelling, so that coral $\Delta^{14} \mathrm{C}$ variations are not likely to reflect a local upwelling signal. The coastal geomorphology is such that no significant rivers flow into the coastal region at this location, minimizing the potential impacts of local runoff. Furthermore, the wide continental shelf in this area permitted sampling of corals from $\sim 3$ $\mathrm{km}$ offshore, further minimizing the probability of impacts from coastal processes and increasing the likelihood that the measurements are representative of the northern Caribbean Sea.

Fed from the northern subtropical, tropical and equatorial gyres, as defined by Mayer and Weisberg (1993), northern Caribbean water $\Delta^{14} \mathrm{C}$ should be controlled by the proportion of water from each of the sources and the $\Delta^{14} \mathrm{C}$ value of the sources. If one can constrain the time-varying ${ }^{14} \mathrm{C}$ content of each of the source waters, then one can theoretically calculate the proportion of each water mass influencing a $\Delta^{14} \mathrm{C}$ record of the northern Caribbean. Existing coral records from Bermuda and Brazil enable the estimation of the subtropical and equatorial end members so that such a calculation can be made with the Puerto Rico coral $\Delta^{14} \mathrm{C}$ record. For the purposes of this paper, equatorial water refers to undifferentiated water from both the tropical and equatorial gyres, the two of which have lower $\Delta^{14} \mathrm{C}$ values because of the influence of upwelling from along the West African coast. Equatorial upwelling taps relatively shallow water (Weingartner and Weisberg 1991) with $\Delta^{14} \mathrm{C}$ values close to the surface water and is therefore considered to be only a minor contributor to the regional $\Delta^{14} \mathrm{C}$ values. 


\section{Analytical methods}

A $245-\mathrm{cm}$ core was collected in $\sim 5 \mathrm{~m}$ of water from a massive coral head of Montastraea faviolata at Turrumote Reef $\left(17.933^{\circ} \mathrm{N}, 67.001^{\circ} \mathrm{W}\right)$ offshore from La Parguera, Puerto Rico in August of 2004. The coral core was cut into 5-mm thick slabs along the primary growth axis, cleaned with deionized water in a sonicator, and Xradiographed to display the annual density banding. Nominally annual samples of coral powder were milled with a Dremel $\AA^{\circledR}$ tool mounted on a computer-controlled drilling stage using the X-radiographs as a guide to ensure that one density band couplet was sampled for each sample. Each sample is composed of a dense band and the less dense band laid down just previously, and labeled with the year the dense band was created. Assuming an early summer date for the formation of the dense band (Watanabe et al. 2002) results in annual samples approximately centered on January of the year with which they are labeled. Each annual sample was analyzed for $\Delta^{14} \mathrm{C}$ between 2004 and 1950 , and before 1950 , every $5^{\text {th }}$ year was analyzed back to 1755 , with the earliest sample representing 1751. Errors in the date assigned to individual coral samples are less likely near the top of the coral, but the possibility of a mistake increases with the years counted, and we estimate the error at the bottom of the core to be \pm 1 year.

The samples were prepared and analyzed for radiocarbon at Lawrence Livermore National Laboratory Center for Accelerator Mass Spectrometry (Davis et al. 1990). Coral aragonite was converted to graphite by reacting 2.5-7.5 mg aliquots of sample with $85 \%$ phosphoric acid in evacuated Vacutainers ${ }^{\circledR}$ and graphitizing the resulting $\mathrm{CO}_{2}$ using an $\mathrm{Fe}$ catalyst and $\mathrm{H}_{2}$ as the reducing agent (Vogel et al. 1987). A background subtraction was determined using ${ }^{14} \mathrm{C}$-free calcite, and analytical precision was monitored with standard reference materials analyzed with the samples. Average precision was $0.32 \%$ (fractional error) with reported errors on each sample averaging 3.2\%o. Results are reported in age-corrected $\Delta^{14} \mathrm{C}$ as defined by (Stuiver and Polach 1977), and are corrected for a uniform $\delta^{13} \mathrm{C}$ value of $-2 \%$.

\section{A mixing model}

A two end-member mixing model was used to describe the percentage of subtropical water, represented by the Bermuda coral of Druffel (1989), versus equatorial 
water, represented by the Abrolhos Bank, Brazil coral record of Druffel (1996), referred to as Cabo. The Puerto Rico coral is described as a percentage along the mixing line between the Cabo coral and the Bermuda coral for each year in the model using the formulas:

$$
\% E q .=\frac{P-B}{C-B}, \text { and } \% S t .=1-\% E q .
$$

Where $\%$ Eq. and $\%$ St. represent the percentages of equatorial and northern subtropical water. $\mathrm{P}, \mathrm{B}$, and $\mathrm{C}$ are the $\Delta^{14} \mathrm{C}$ values of the Puerto Rico, Bermuda, and Cabo corals respectively. Analytical error was propagated through the above equations using the standard propagation of error formula (Beers 1957) and assuming that the different corals are independent:

$$
\sigma_{\% E q}^{2}=\left(\frac{\partial \% E q}{\partial P}\right)^{2} \sigma_{P}^{2}+\left(\frac{\partial \% E q}{\partial B}\right)^{2} \sigma_{B}^{2}+\left(\frac{\partial \% E q}{\partial C}\right)^{2} \sigma_{C}^{2}
$$

The model begins in 1963, when the gradient between the equatorial and subtropical waters becomes great enough that we can differentiate the two water masses from the corals with confidence from single-point measurements. The Cabo $\Delta^{14} \mathrm{C}$ data are centered on 19xx.5, and the Bermuda data are centered on 19xx.8 (except 1983.3), so the dates are rounded up (except 1983.3 which is rounded down) in order to compare with the Puerto Rico coral data which are centered on the beginning of the year (i.e., 19xx.0). An alternate method was also calculated whereby the Bermuda and Brazil data were interpolated so that they were centered on the beginning of the year, like the Puerto Rico data, however the results were essentially the same, so they are not shown. The Cabo coral was collected in December of 1982 and the Bermuda coral in 1983, so the last nominal year of the model is 1983 .

The sensitivity of the model to time lags between the Puerto Rico coral $\Delta^{14} \mathrm{C}$ and the end member coral $\Delta^{14} \mathrm{C}$ records was tested by shifting the end member records so that they led the Puerto Rico coral in order to simulate the time it might take for a signal to reach Puerto Rico. It is unreasonable to have them lag the Puerto Rico coral record since water moves toward Puerto Rico from the northern subtropical and equatorial regions. How long is an appropriate lead time? Doubling the maximum travel time seems a reasonable estimate, recognizing that any individual water parcel may take much longer 
or much shorter to travel the distance. The zonal speed of drifters in the North Equatorial Current (NEC) around $40^{\circ} \mathrm{W}$ longitude is $10-20 \mathrm{~cm} / \mathrm{s}$ (Lumpkin and Garzoli 2005). At that velocity it would take approximately 6-11 months to travel the $2900 \mathrm{~km}$ to south western Puerto Rico. The northern limb of the South Equatorial Current has an average zonal speed of $33 \pm 11 \mathrm{~cm} / \mathrm{s}$ at $30^{\circ} \mathrm{W}$ (Lumpkin and Garzoli 2005), implying that it might take $\sim 5$ months to travel the $4400 \mathrm{~km}$ from the $\operatorname{SEC}\left(2^{\circ} \mathrm{N}, 30^{\circ} \mathrm{W}\right)$ to our study site $\left(17^{\circ} \mathrm{N}\right.$, $\left.67^{\circ} \mathrm{W}\right)$. Annual resolution causes any signal with a travel time of less than a year appear to be instantaneous, so adjusting the data to simulate one-year lead times encompasses real lead times of up to 2 years.

The Cabo coral site is situated at $17.5^{\circ} \mathrm{S}$ and $39.3^{\circ} \mathrm{W}$ and the South Brazil Current, which runs past this site, is fed by the South Equatorial Current (SEC; Figure 1). Although the $\Delta^{14} \mathrm{C}$ of the SEC would be ideal to monitor directly as an end member for this mixing exercise, a continuous time series of $\Delta^{14} \mathrm{C}$ has not been made from an appropriately situated coral. Hydrographic data indicate that the $\Delta^{14} \mathrm{C}$ at the Cabo site is similar to that of the SEC, but can be slightly higher than in the SEC (Stuiver and Ostlund 1980; Takahashi et al. 1995), presumably because of the influence of waters from the subtropical South Atlantic. The mixing model using these data should be considered a maximum estimate of the amount of equatorial influence at Puerto Rico in light of these facts.

\section{RESULTS}

\section{Pre-Bomb Variability}

The entire coral $\Delta^{14} \mathrm{C}$ record from Puerto Rico is shown in Figure 2 along with other Atlantic coral records for context. The bomb carbon signal is an enormous $\Delta^{14} \mathrm{C}$ increase beginning in the late 1950s, which peaks in the early to middle 1970s. The prebomb average from 1751 to 1950 at Puerto Rico is $-51 \pm 1.2 \%$ ( $2 \sigma$ standard error, $\mathrm{N}=41)$, with a standard deviation of $3.7 \%(1 \sigma)$. The average at Puerto Rico is less than the pre-bomb average of the North Atlantic gyre measured from corals at Bermuda $-45 \pm$ $1.6 \%$ (1885-1953, 2 $\sigma$ standard error, $\mathrm{N}=35)$ by Druffel (1997b), as expected from the gross distribution of ${ }^{14} \mathrm{C}$ in the ocean. The small decreasing trend in the data between 
1751 and $1950(-0.0095 \%$ o/year, $\mathrm{p}=0.34)$ is not significant because of the large amount of higher frequency variance in the records (Figure 3). Limiting the regression period to between 1900 and 1950 produced a significant slope of $-0.15 \pm 0.05 \%$ ooear $(\mathrm{p}=0.02)$ over the period when atmospheric $\Delta^{14} \mathrm{C}$ was dropping precipitously (Figure 3 ) due to the input of ${ }^{14} \mathrm{C}$-free $\mathrm{CO}_{2}$ from fossil-fuel burning (Suess effect, Suess 1953).

The total range of pre-bomb values at Puerto Rico are $-59 \%$ to $-43 \%$ (Figure 2), less than the range found in Bermuda and the Florida Keys (-34\%o to -64 \%o, Druffel 1997b). Typical variations in the pre-bomb $\Delta^{14} \mathrm{C}$ record at Puerto Rico are less than 10 $\%$ between samples, but these are still substantially greater than the atmospheric variability from tree ring records (Figure 3), and therefore must be evidence of advection and/or mixing. The rapid depletion between 1950 and 1951 that is sustained until the mid-1950s when the bomb-carbon spike enters the system, is of particular interest because the Puerto Rico record is annually resolved during this period, and we have multiple coral records from around the Atlantic at this time (Figure 4), allowing for a more complete spatial picture of the event.

\section{Post-Bomb Variability}

Radiocarbon values in the Puerto Rico coral increase rapidly beyond pre-bomb values beginning in 1959 (Figure 5). The rate of increase levels off between 1960 and 1963, after which radiocarbon values continue to increase steadily until they peak around $130 \%$ in the early 1970s. The absolute maximum value is $147 \%$, reached in 1976 as part of a two-year peak that rises above the sustained maximum around $130 \%$. The rate of decay between 1972 and 2005 can be estimated at $-2.4 \%$ /year $\left(r^{2}=0.94\right)$ by ordinary least squares linear regression. The rate of decay is more correctly estimated with an exponential fit, resulting in the following equation:

$\Delta^{14} \mathrm{C}=7.34 \times 10^{22} \cdot \mathrm{e}^{-0.02417 \text { yearAD }} \quad \mathrm{r}^{2}=0.94$

A two end-member mixing model describing the percentage of subtropical water versus equatorial water in the northern Caribbean between 1963 and 1983 can be calculated with the coral $\Delta{ }^{14} \mathrm{C}$ data as described above (Figure 6). The earlier period 
from 1963-1970 is consistent with a subtropical origin for much of the water bathing southwestern Puerto Rico, and the latter period from 1977-1983 is interpreted as representing mostly equatorial water at the site. The two periods are separated by a transitional period between 1970 and 1976 with large interannual changes in the amount of either water mass. Specifically, the proportion of equatorial water increases sharply in 1970 and remains high except for 1975 and 1976 when the two-year peak in Puerto Rico coral $\Delta^{14} \mathrm{C}$ (1975-1976) is interpreted as two years of strong northern subtropical influence.

The increasing influence of equatorial water at Puerto Rico over this time period is a robust signal that does not disappear when the phasing of the coral records are changed in the model to represent the time taken by water parcels to travel between the study areas (Figure 6). Results from the first two years of the mixing model are highly dependent on the lead/lag relationship, which makes sense because the signals are rapidly changing and the surface gradient due to the bomb carbon input are still developing, so the end member $\Delta^{14} \mathrm{C}$ values were not as differentiated. If only the Brazil record leads the Bermuda and Puerto Rico records, the model breaks down for 1963 and 1964 because all three $\Delta^{14} \mathrm{C}$ records are indistinguishable given the analytical error. The percentages of subtropical versus equatorial water in the model change substantially during 1965-1970 depending on the lead/lag relationships because of the rapid bomb carbon input to the ocean. However, the amount of equatorial water is generally lower during 1965-1970 (average $32 \pm 24 \%$ equatorial water) than during 1977-1983 (average $89 \pm 10 \%$ equatorial water), no mater what lead/lag relationship is used in the model.

It should be noted again that the percentage of equatorial water calculated from this model is a maximal estimate because of the possibility that the Cabo coral is recording a mixed equatorial and South Atlantic gyre signal. The Cabo coral is therefore probably biased towards higher $\Delta^{14} \mathrm{C}$ values than the actual equatorial water end member. GEOSECS seawater $\Delta^{14} \mathrm{C}$ measurements from the fall of 1972 are used to estimate the effects of this bias on the results of the mixing model. These data represent the only time when we have both northern gyre and south equatorial current seawater $\Delta^{14} \mathrm{C}$ measurements in the same year. The results of this test indicate that our end-member corals capture a range between 16 to $53 \%$ equatorial water and $47 \%$ to $84 \%$ North 
Atlantic gyre water, instead of $0 \%$ to $100 \%$ of each water mass as depicted in the model for simplicity.

An alternate interpretation to explain an apparent switch in the Puerto Rico coral $\Delta \Delta^{14} \mathrm{C}$ record from primarily subtropical to primarily equatorial is that the equatorial end member used in the model (the Cabo coral) became more subtropical and thus more like the Puerto Rico coral record rather than any actual change in the Puerto Rico coral $\Delta^{14} \mathrm{C}$. This interpretation can be discounted as the primary signal in the model because, if true, than the relationship between the Bermuda coral $\Delta{ }^{14} \mathrm{C}$ and the Puerto Rico coral $\Delta{ }^{14} \mathrm{C}$ should have remained relatively constant. The Puerto Rico coral $\Delta^{14} \mathrm{C}$ curve in Figure 5 clearly overlaps with the Bermuda coral record curve before 1970, and after 1970 the Puerto Rico coral $\Delta^{14} \mathrm{C}$ is clearly significantly lower than the Bermuda coral $\Delta^{14} \mathrm{C}$ (except for 1974-1975). Changes in the amount of subtropical water around the Cabo coral may exaggerate the amount of equatorial water found in the Puerto Rico coral $\Delta^{14} \mathrm{C}$ signal, as described above, but such changes cannot completely account for the observed shift in $\Delta \Delta^{14} \mathrm{C}$ at Puerto Rico.

\section{DISCUSSION}

\section{Pre-Bomb Variability}

The Suess effect is not resolvable with these data because of the large interannualto interdecadal- scale fluctuations (Figure 3). It is possible that the significant trend between 1900 and $1950(-0.15 \pm 0.05 \%$ /year, $\mathrm{p}=0.02)$ is indeed due to anthropogenic input of ${ }^{14} \mathrm{C}$-depleted carbon to the system, and that the circulation changes do not influence the $\Delta^{14} \mathrm{C}$ during that time period. However, the significance of the trend is highly dependent on the period of regression. Extending the regression period to 18801950 , results in a completely insignificant trend $(-0.02 \pm 0.10 \%$ year, $\mathrm{p}=0.70)$, and extending the regression period by just two years to 1900-1952 increases the slope considerably $(-0.25 \pm 0.12 \%$ o/year, $\mathrm{p}=0.002)$. Therefore, we conclude that $\Delta^{14} \mathrm{C}$ changes due to horizontal and vertical advection in the Northern Caribbean swamp the atmospheric signal of hydrocarbon use during the pre-bomb era. 
Early work with $\Delta^{14} \mathrm{C}$ from corals that grew in the Florida Keys and Belize identified a decreasing trend between 1900 and the 1950s that was identified as the Suess effect (Druffel 1980; Druffel and Linick 1978). However, later work has identified a strong depletion in the Florida Keys corals between the 1940s and the 1950s that has been attributed to ocean dynamics rather than equilibration with atmospheric radiocarbon (Druffel 1997a; Druffel 1997b; Guilderson et al. 2005). A closer look at radiocarbon records from this time indicates that out of seven records to span the 1950s, five of them exhibit a rapid depletion to about -65\%o between 1950 and 1953 (Figure 4). The records exhibiting this behavior come from Porto de Galinhas, Brazil $\left(8^{\circ} \mathrm{S}\right)$, Puerto Rico $\left(17^{\circ} \mathrm{N}\right)$, Glovers Reef, Belize $\left(17^{\circ} \mathrm{N}\right)$, Pickles Reef and the Rocks Reef in the Florida Keys $\left(25^{\circ} \mathrm{N}\right)$. The two records that do not exhibit this strong depletion are from the corals located farthest north and farthest south, Bermuda $\left(34^{\circ} \mathrm{N}\right)$ and Cabo $\left(17^{\circ} \mathrm{S}\right)$. The event seems to have started rapidly because the records with values for 1950 (Puerto Rico, Pickles Reef and Glovers Reef) show the seawater $\Delta^{14} \mathrm{C}$ to be close to $-54 \%$ in that year, but the next sample in all three records (1951, 1952, and 1952.5 respectively) was close to $-65 \%$. Ocean dynamics must be at play given that the isotopic equilibration time between the atmosphere and the surface ocean is on the order of 10 years.

Four scenarios are possible to explain the rapid drop in $\Delta^{14} \mathrm{C}$ at all of these sites. The first explanation is that the depletions are simply measurement error. Previous studies likely did not make much of the $10 \%$ depletion because one sigma error bars on $\Delta \Delta^{14} \mathrm{C}$ measurements hover around 3-4 \%o and the time resolution is such for most of the records that the early 1950s are represented by only one or two points. The likelihood of five independent records having an analytical "hiccup" at the same time is very low, so we choose to reject this first explanation. The second possibility is local ventilation of low $\Delta^{14} \mathrm{C}$ waters at each of these sites. Simultaneous local upwelling events at all of these sites, which are in totally different surface wind regimes and which have different propensities toward upwelling, seems highly unlikely, so we also choose to reject this explanation. The third possible scenario is that a large increase in upwelling lowered the $\Delta{ }^{14} \mathrm{C}$ value of the equatorial end-member that mixes into the Caribbean and Gulf Stream waters. The Porto de Galinhas coral, which is representative of the SEC, has a minimum value of $-64 \%$ in 1952, indicating that the equatorial end-member was not more depleted 
with respect to ${ }^{14} \mathrm{C}$ than the waters bathing the other sites. Thus, the third scenario is also rejected, leaving one remaining scenario to be explored.

The fourth and most plausible explanation is that all of these sites were strongly influenced by low $\Delta^{14} \mathrm{C}$ equatorial surface waters, implying that the proportion of equatorial versus northern subtropical water in the surface inflow of the Caribbean is highly variable on interannual time scales. Increasing the surface transport of equatorial waters into the Caribbean, may have an impact on the total amount of South Atlantic water entering the Caribbean because $\sim 50 \%$ of the $\sim 13 \mathrm{~Sv}$ MOC return flow coming from the South Atlantic is in the topmost 100 meters (Schmitz and Richardson 1991). The duration of this increased equatorial-water transport is unknown because the $\Delta^{14} \mathrm{C}$ at all sites begins to rise rapidly in the mid 1950s due to enormous atmospheric input from thermonuclear bomb testing.

\section{Water Mass Changes}

The results of the mixing model (Figure 6) are intriguing because they indicate that the proportion of water from equatorial sources versus northern subtropical sources bathing southwestern Puerto Rico changes on interannual to decadal time scales as hypothesized by Wilson and Johns (1997). It must be noted that the low ${ }^{14} \mathrm{C}$, equatorially sourced, water is a mixture of North Atlantic and South Atlantic water, and is not a pure South Atlantic signal. However, increases in the flux of equatorial water likely means an increase in the amount of South Atlantic water that is carried with it.

There are two ways of looking at the $\Delta^{14} \mathrm{C}$ variability in the Puerto Rico coral: 1) the signal is that of a well-mixed Caribbean surface flow and represents the average proportion of water parcels from each source in the Caribbean, or, more conservatively, 2) the signal is that of the northern Caribbean, just south of Puerto Rico and signifies the sources of water in that region only. The only way to distinguish which hypothesis is correct is to look at the spatial distribution of $\Delta^{14} \mathrm{C}$ in the Caribbean, either in the modern ocean or from the geologic record. Seawater $\Delta^{14} \mathrm{C}$ records are too rare in the Caribbean to be able to determine any spatial patterns, especially if they are also time variant, so the best way to achieve this goal is to examine $\Delta^{14} \mathrm{C}$ time series from other corals in the Caribbean. The only other long time series in the Caribbean is the Glovers Reef record 
from Belize (Druffel 1980), which is situated along the eastern edge of the Yucatan Peninsula, just south of where the narrowly focused Caribbean Current impinges on the continent (Richardson 2005). The $\Delta^{14} \mathrm{C}$ record from the Belize coral has been interpreted as a signal from the western boundary current because of this fact (Druffel 1989), and as such, it may be more of a mixed Caribbean signal rather than representative of the spatial variability due to different source waters. More records from the eastern Caribbean are needed to address the issue of spatial variability of $\Delta^{14} \mathrm{C}$ in the Caribbean as waters enter the basin. We conservatively assume that the Puerto Rico coral $\Delta{ }^{14} \mathrm{C}$ record is representative of the northern Caribbean at approximately $67^{\circ}$ longitude for the rest of our analysis.

Focusing on the Belize record, this coral shows much higher values in the $1960 \mathrm{~s}$ than either the Bermuda or the Puerto Rico corals (Figure 5). Druffel (1989) attributed these high values to the formation of $18^{\circ}$ mode water in the gyre influencing the Bermuda coral. Since the gyre water feeds into the Caribbean along with lower $\Delta^{14} \mathrm{C}$ equatorial water, the Belize coral should have lower $\Delta^{14} \mathrm{C}$ values than the Bermuda coral if the Belize coral actually represents a mixed Caribbean water signal. However, the Belize coral $\Delta{ }^{14} \mathrm{C}$ is higher than the Bermuda and Puerto Rico coral $\Delta{ }^{14} \mathrm{C}$ records, so ${ }^{14} \mathrm{C}$ must be added to the system in the Caribbean. If one looks into more detail at the circulation surrounding Glovers Reef in the Gulf of Honduras, one finds that the reef platform is bathed by a small cyclonic gyre with relatively weak and spatially variable currents (Centurioni and Niiler 2003; Tang et al. 2006). A logical explanation for the relative enrichment of the Glovers Reef coral is that the relative isolation of the Gulf of Honduras, the strong thermal stratification, and the resultant very shallow mixed layer permitted the surface waters around Glovers Reef to equilibrate with the atmosphere more rapidly. This interpretation can explain why Puerto Rico, situated close to the Caribbean source waters, was not similarly enriched with respect to ${ }^{14} \mathrm{C}$ relative to the Bermuda coral during the 1960s.

The two-year enrichment of Puerto Rico coral $\Delta^{14} \mathrm{C}$ in 1975 and 1976 indicates a short period when northern subtropical water strongly influenced the northern Caribbean, punctuating a longer period of more equatorial influence (Figure 6). The interannual event coincides with an El-Nino Southern Oscillation (ENSO) cold-phase event (La 
Nina) in the Pacific and an extensive cold anomaly in the northern Tropical Atlantic with seasonal SST anomalies $<-1^{\circ} \mathrm{C}$ in the Caribbean. However, the proximal cause of the event remains unknown despite examinations of Atlantic region seasonal sea level pressure, wind velocity, and sea surface temperature anomalies over the calendar years of 1974-1977 (compared to the seasonal means between 1948-2005). Further investigation is needed to determine the causes of this event and other interannual-scale events (e.g., the early 1950s depletion) in the record

Given that much of the return flow for MOC occurs in the surface and likely comes through the Caribbean Sea, it is reasonable to speculate on the implications of the water mass changes at Puerto Rico as if they represent changes in the volume of return flow. The short length of the model output compared to variability in the AMO prohibits a quantitative analysis, however it is worth noting the qualitative agreement. Vellinga and Wood (2002) simulate that when MOC shuts down, the North Atlantic becomes cooler. It is possible that similar, if less pronounced, changes occur on multidecadal timescales. The idea is that vigorous MOC activity transports heat from the South Atlantic to the North Atlantic during the positive AMO phase and the resulting weaker MOC leads to a cooler North Atlantic during the negative AMO phase.

If this model is correct, the decay of the positive phase should be associated with less vigorous MOC and therefore less low- $-{ }^{14} \mathrm{C}$ equatorial water returning into the Caribbean. Conversely, the decay of the negative phase of AMO should be associated with stronger overturning circulation and thus more low- $-{ }^{14} \mathrm{C}$ equatorial water flowing into the Caribbean. Figure 6 shows that during the early period of our model, 1963-1975, one would predict less equatorial water in the Caribbean and during the latter period, 1975-1983, one would predict more equatorial water, exactly the pattern predicted by the model. The data are suggestive that the observed circulation changes might be coincident with the AMO, but much longer time series of similar data are needed to prove a consistent relationship.

\section{Mechanisms for Transport}

The Puerto Rico coral was bathed by seawater with less ${ }^{14} \mathrm{C}$ during the early 1980s compared to the 1960 s and the source of that ${ }^{14} \mathrm{C}$ depletion is likely to be waters 
from the equatorial region where upwelling is a consistent source of ${ }^{14} \mathrm{C}$-depleted DIC. Current theories of how water is transported northward across the equator include: 1) eddy shedding from the North Brazil Current Retroflection (Didden and Schott 1993; Johns et al. 1990; Richardson et al. 1994), 2) direct flow into the southern Caribbean by the seasonal northwestward flowing Guyana Current via the North Brazil Current (Lumpkin and Garzoli 2005), and 3) northward transport of surface waters by Ekman drift in the ocean interior (Halliwell et al. 2003; Lumpkin and Garzoli 2005; Mayer and Weisberg 1993). In order to get equatorial ${ }^{14} \mathrm{C}$-depleted waters around Puerto Rico, it has to be transported northward to the latitude of Puerto Rico, either before or after entering the Caribbean. Northward surface transport at this latitude $\left(17^{\circ} \mathrm{N}\right)$ is primarily by winddriven Ekman drift on time scales greater than seasons (Mayer and Weisberg 1993), thus it follows logically that the coral $\Delta^{14} \mathrm{C}$ signal in Puerto Rico might be related to the tradewind strength on decadal timescales.

To test this theory, we compared the tropical Atlantic wind velocities between the early period (1963-1970) when subtropical waters dominate the Puerto Rico coral signal, and the late period (1977-1983) when equatorial waters dominate the Puerto Rico coral signal by creating a map of the differences in NCEP wind velocities between the two time periods (not shown). As expected from our hypothesis, the trade winds were stronger during the latter period, consistent with the proposed increase in Ekman transport during that time. To further investigate the relationship between the wind data and the results of our mixing model, we created a spatial correlation map of NCEP zonal wind velocity with our mixing model results (Figure 7). The largest region of strong negative correlation is very similar to the region of the largest difference in wind velocity between 1963-1970 and 1977-1983, and roughly encompasses the northern trade wind belt. Annually resolved zonal wind speed data for two regions in the Atlantic are shown along with the mixing model results in Figure 8 to demonstrate that the difference between the two periods reflects a robust change in the winds with time. The time series of the winds shows a trend over the same period as the coral $\Delta^{14} \mathrm{C}$ data and the winds from the equatorial box are strongly correlated to the model $\left(r^{2}=0.69\right)$. Serial autocorrelation inherent in data with similar trends weakens the significance $(\mathrm{p}=0.66)$, 
but the temporal correlation of the theoretical forcing and the predicted outcome is suggestive that increased Ekman transport is a viable explanation of the $\Delta^{14} \mathrm{C}$ data.

\section{CONCLUSIONS}

1. The Suess effect is not apparent in coral $\Delta{ }^{14} \mathrm{C}$ from southwestern Puerto Rico. Interannual- to interdecadal-scale variations in $\Delta^{14} \mathrm{C}$ are large and make the longterm trends in the data insignificant.

2. The radiocarbon content of the waters bathing southwestern Puerto Rico changes on interannual to multidecadal time scales in response to ocean dynamics.

3. A major contributor to this variance is the proportion of equatorial versus subtropical water in this area. The timing of water mass changes between 1964 and 1983 is consistent with predictions based on a link between the Atlantic Multidecadal Oscillation and Meridional Overturning Circulation.

4. We propose that the observed changes in the northern extent of equatorial water masses are caused by an increase in trade winds and the accompanying increase in northward Ekman transport of the surface waters.

\section{ACKNOWLEDGEMENTS}

The authors wish to acknowledge funding from the Elsie and William Knight Oceanographic Fellowship and the United States National Science Foundation grant number OCE-0327420. Radiocarbon analyses were performed under the auspices of the U.S. Department of Energy by the University of California Lawrence Livermore National Laboratory (contract W-7405-Eng-48). Discussions with Robert Weisberg, Denis Mayer, and Jyotika Virmani were very helpful. Amos Winter acted as our liaison with the University of Puerto Rico and introduced us to Milton Carlo who provided invaluable support for the fieldwork. Impromptu help in the field by Peter K. Swart was also greatly appreciated. Comments by Benjamin Flower and Frank Muller-Karger helped the authors improve earlier versions of the manuscript. Data will be archived with the U.S. National Oceanic and Atmospheric Administration's World Data Center for Paleoclimatology.

\section{REFERENCES}

Beers Y (1957) Introduction to the Theory of Error, Addison-Wesley-Longman, Reading, Massachusetts pp 66 
Broecker WS (1998) Paleocean circulation during the last deglaciation: A bipolar seesaw? Paleoceanography, 13: 119-121.

Broecker WS, Olson EA (1961) Lamont radiocarbon measurements VIII. Radiocarbon, 3: 176-204.

Centurioni LR, Niiler PP (2003) On the surface currents of the Caribbean Sea. Geophys Res Lett, 30.

Davis JC, Proctor ID, Southon JR, Caffee MW, Heikkinen DW, Roberts ML, Moore TL, Turteltaub KW, Nelson DE, Loyd DH, Vogel JS (1990) LLNL/UC AMS facility and research program. Nucl Instrum Methods Phys Res Sect B, 52B: 269-272.

Delworth TL, Mann ME (2000) Observed and simulated multidecadal variability in the Northern Hemisphere. Clim Dyn, 16: 661-676.

Didden N, Schott F (1993) Eddies in the North Brazil Current retroflection region observed by Geosat altimetry. J Geophys Res, 98: 20121-20131.

Druffel ERM (1980) Radiocarbon in annual coral rings of Belize and Florida. Radiocarbon, 22: 363-371.

Druffel ERM (1982) Banded corals; changes in oceanic carbon-14 during the Little Ice Age. Science, 218: 13-19.

Druffel ERM (1989) Decadal time scale variability of ventilation in the North Atlantic: high-precision measurements of bomb radiocarbon in banded corals. J Geophys Res, 94: 3271-3285.

Druffel ERM (1996) Post-bomb radiocarbon records of surface corals from the tropical Atlantic Ocean. Radiocarbon, 38: 563-572.

Druffel ERM (1997a) Geochemistry of corals: proxies of past ocean chemistry, ocean circulation and climate. Proc. Natl. Acad. Sci. U. S. A., 94: 8354-8361.

Druffel ERM (1997b) Pulses of rapid ventilation in the North Atlantic surface ocean during the past century. Science, 275: 1454-1457.

Druffel ERM (2002) Radiocarbon in Corals: Records of the Carbon Cycle, Surface Circulation and Climate. Oceanography, 15: 122-127.

Druffel ERM, Griffin S (1993) Large variations of surface ocean radiocarbon: evidence of circulation changes in the southwestern Pacific. J Geophys Res, 98: 20,249220,259 .

Druffel ERM, Linick TW (1978) Radiocarbon in annual coral rings of Florida. Geophys Res Lett, 5: 913-916.

Enfield DB, Mestas-Nuñez AM, Trimble PJ (2001) The Atlantic multidecadal oscillation and its relation to rainfall and river flows in the continental U.S. Geophys Res Lett, 28: $2077-2080$.

Fratantoni DM (2001) North Atlantic surface circulation during the 1990's observed with satellite-tracked drifters. J Geophys Res, 106: 22,067-022,093.

Ganopolski A, Rahmstorf S (2001) Rapid changes of glacial climate simulated in a coupled climate model. Nature, 409: 153-158.

Guilderson TP, Cole JE, Southon JR (2005) Pre-bomb $\Delta{ }^{14} \mathrm{C}$ variability and the Suess effect in Cariaco Basin surface waters as recorded in hermatypic corals. Radiocarbon, 47: 57-65.

Guilderson TP, Schrag DP, Cane MA (2004) Surface water mixing in the Solomon Sea as documented by a high-resolution coral ${ }^{14} \mathrm{C}$ record. J Clim, 17: 1147-1156. 
Guilderson TP, Schrag DP, Kashgarian M, Southon J (1998) Radiocarbon variability in the western equatorial Pacific inferred from a high-resolution coral record from Nauru Island. J Geophys Res, 103: 24,641-624,650.

Halliwell GR, Weisberg RH, Mayer DA (2003) A synthetic float analysis of upper-limb meridional overturning circulation interior ocean pathways in the tropical/subtropical Atlantic. In Goni GJ, Malanotte-Rizzoli P (eds) Interhemispheric Water Exchange in the Atlantic Ocean. Elsevier, Amsterdam, pp 93-136.

Johns WE, Lee TN, Schott FA, Zantopp RJ, Evans RH (1990) The North Brazil Current retroflection seasonal structure and eddy variability. J Geophys Res, 95: 2210322120.

Johns WE, Townsend TL, Fratantoni DM, Wilson WD (2002) On the Atlantic inflow to the Caribbean Sea. Deep Sea Res I, 49: 211-243.

Lumpkin R, Garzoli SL (2005) Near-surface circulation in the tropical Atlantic Ocean. Deep-Sea Research Part I-Oceanographic Research Papers, 52: 495-518.

Mahadevan A (2001) An analysis of bomb radiocarbon trends in the Pacific. Marine Chemistry, 73: 273-290.

Mayer DA, Weisberg RH (1993) A description of COADS surface meteorological fields and the implied Sverdrup transports for the Atlantic Ocean from $30^{\circ} \mathrm{S}$ to $60^{\circ} \mathrm{N}$. J Phys Oceanogr, 23: 2201-2221.

Mazeika PA, Kinder TH, Burns DA (1983) Measurements of subtidal flow in the Lesser Antilles passages. J Geophys Res, 88: 7783-4488.

Metcalf WG, Stalcup MC, Zemanovic ME (1971) Hydrographic station data from Atlantis II Cruise 56 to the southeastern approaches to the Caribbean Sea, FebruaryApril 1970., Rep. WHOI 71-13, Woods Hole Oceanographic Institution, Woods Hole, MA, pp 103.

Nydal R, Løvseth K (1996) Carbon-14 Measurements in Atmospheric CO2 from Northern and Southern Hemisphere Sites, 1962-1993, Rep. ORNL/CDIAC-93, NDP057, Carbon Dioxide Information Analysis Center, Oak Ridge National Laboratory, Oak Ridge, Tennessee, pp 67.

Ostlund HG, Grall C (1987) North and Tropical Atlantic tritium and radiocarbon, R.S.M.A.S., University of Miami, Miami, Florida, pp 277.

Parr AE (1937) A contribution to the Hydrography of the Caribbean and Cayman Seas, based upon the observations made by the research ship "Atlantis", 1933-1934. Bulletin of the Bingham Oceanographic Collection, 5: 110.

Reimer P, Baillie MGL, Bard E, Bayliss A, Beck W, J., Bertrand CJH, Blackwell PG, Buck CE, Burr GS, Cutler KB, Damon PE, Edwards RL, Fairbanks RG, Friedrich M, Guilderson TP, Hogg AG, Hughen KA, Kromer B, McCormac G, Manning S, Ramsey CB, Reimer RW, Remmele S, Southon JR, Stuiver M, Talamo S, Taylor FW, van der Plicht J, Weyhenmeyer CE (2004) INTCAL04 Terrestrial Radiocarbon Age Calibration, 0-26 Cal kyr bp. Radiocarbon, 46: 1029-1058.

Rhein M, Kirchner K, Mertens C, Steinfeldt R, Walter M, Fleischmann-Wischnath U (2005) Transport of South Atlantic water through the passages south of Guadeloupe and across $16^{\circ}$ N, 2000-2004. Deep Sea Research Part I, 52: 2234-2249.

Richardson PL (2005) Caribbean Current and eddies as observed by surface drifters. Deep-Sea Research Part Ii-Topical Studies in Oceanography, 52: 429-463. 
Richardson PL, Hufford GE, Limeburner R, Brown WS (1994) North Brazil Current retroflection eddies. J Geophys Res, 99: 5081-5093.

Schlesinger ME, Ramankutty N (1994) An oscillation in the global climate system of period 65-70 years. Nature, 367: 723-726.

Schmitz WJ, Richardson PL (1991) On the sources of the Florida Current. Deep Sea Research, 38: S379-409.

Stuiver M, Ostlund HG (1980) GEOSECS Atlantic radiocarbon. Radiocarbon, 22: 25-53.

Stuiver M, Polach HA (1977) Discussion and reporting of ${ }^{14} \mathrm{C}$ data. Radiocarbon, 19: 355-363.

Suess HE (1953) Natural radiocarbon and the rate of exchange of carbon dioxide between the atmosphere and the sea. In Science NRCCoN (ed) Nuclear Processes in Geologic Settings. National Academy of Sciences, Washington D.C., pp 52-56.

Sverdrup HU (1947) Wind-driven currents in a baroclinic ocean: with application to the equatorial currents of the eastern Pacific. Proc. Natl. Acad. Sci. U. S. A., 33: 318-326.

Takahashi T, Peng T-H, Sutherland S (1995) Radiocarbon and CO2 measurements from Tropical Atlantic Study (TTO/TAS), Oak Ridge National Laboratory, U.S. Department of Energy, Oak Ridge, Tennessee

Tang LQ, Sheng JY, Hatcher BG, Sale PF (2006) Numerical study of circulation, dispersion, and hydrodynamic connectivity of surface waters on the Belize shelf. Journal of Geophysical Research-Oceans, 111.

Vellinga M, Wood R (2002) Global climatic impacts of a collapse of the Atlantic thermohaline circulation. Climatic Change, 54: 251-267.

Vogel JS, Southon JR, Nelson DE (1987) Catalyst and binder effects in the use of filamentous graphite for AMS. Nucl Instrum Methods Phys Res Sect B, 29: 50-56.

Watanabe T, Winter A, Oba T, Anzai R, Ishioroshi H (2002) Evaluation of the fidelity of isotope records as an environmental proxy in the coral Montastrea. Coral Reefs, 21: 169-178.

Weingartner T, J., Weisberg RH (1991) On the annual cycle of equatorial upwelling in the central Atlantic Ocean. J Phys Oceanogr, 21: 68-82.

Wilson WD, Johns WE (1997) Velocity structure and transport in the Windward Islands passages. Deep Sea Research, 44: 487-520.

Wust G (1964) Stratification and circulation in the Antillean-Caribbean basins, Columbia University Press, New York pp 


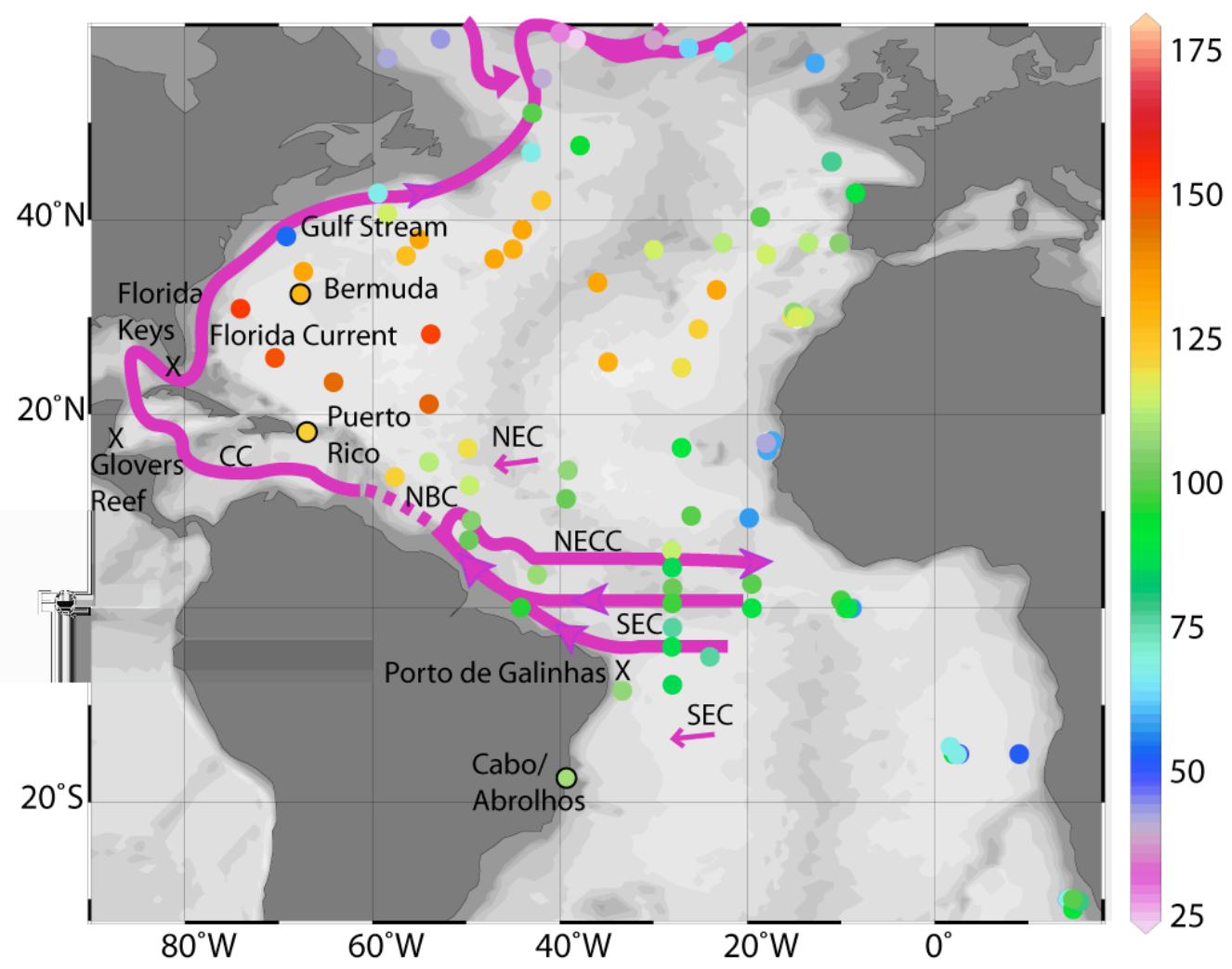

Figure 1: Radiocarbon values of seawater DIC between 1981 and 1983 (Nydal and Løvseth 1996; Ostlund and Grall 1987) plotted with coral radiocarbon values at Bermuda, Puerto Rico and Cabo for 1983 outlined in black. The high level of agreement between these two datasets demonstrates that coral radiocarbon records from these areas accurately reflect the $\Delta^{14} \mathrm{C}$ of the surrounding seawater. Some major currents are labeled (CC - Caribbean Current, NBC - North Brazil Current, NEC - North Equatorial Current, NECC - North Equatorial Counter Current, SEC - South Equatorial Current) and schematically represented by the purple lines and arrows, after the drifter study of (Fratantoni 2001). Other sample sites mentioned in the text are marked with Xs and labeled. 
Table 1: Mean surface $\Delta^{14} \mathrm{C}$ values collected between January 1955 and December $1957^{1}$

$\begin{array}{ccc}\text { Latitude Range } & \begin{array}{c}\text { Average } \Delta^{14} \mathrm{C} \\ \text { (permil) }\end{array} & \begin{array}{c}\text { Standard Error } \\ \text { Number of } \\ \text { measurements }\end{array}\end{array}$

$\begin{array}{cccc}15^{\circ} \mathrm{N} \text { to } 40^{\circ} \mathrm{N} & -49 & 3 & 11 \\ 1^{\circ} \mathrm{N} \text { to } 20^{\circ} \mathrm{S} & -59 & 3 & 8 \\ \text { 1. Data are from Broecker and Olson (1961). }\end{array}$




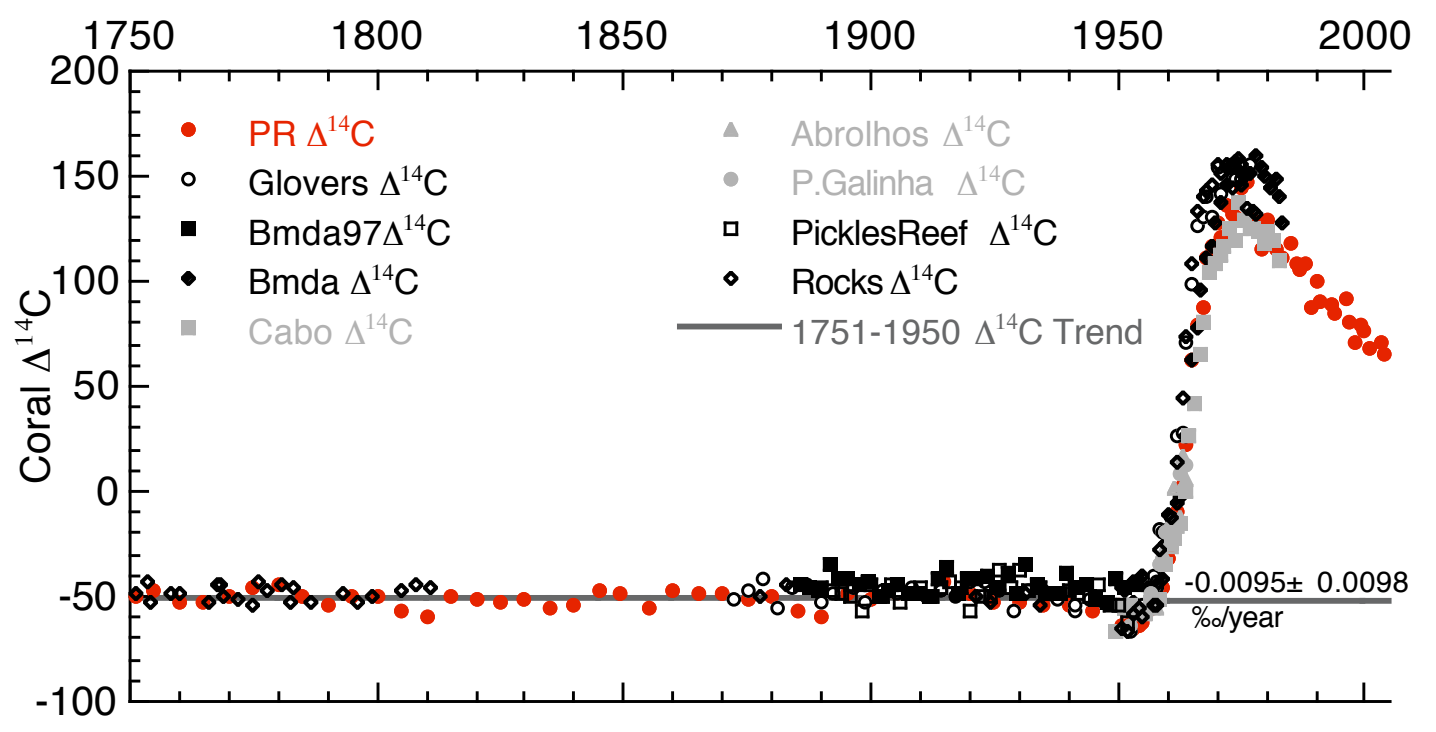

Figure 2: Caribbean and western Atlantic coral $\Delta^{14} \mathrm{C}$ records. New data from Puerto Rico are shown as solid red circles. Data from western boundary current sites in Belize (Glovers) and the Florida Keys (Pickles Reef and The Rocks) are denoted by open symbols. Records from the South Atlantic are plotted in grey (Cabo, Abrolhos, and Punto Galinha), and gyre sites are represented by solid black symbols (Bermuda). The trend line represents the ordinary least squares regression on the Puerto Rico coral data from 1751 to 1950 , with the slope and $95 \%$ confidence intervals on the slope, illustrating that the Suess effect is not a significant portion of the variance in $\Delta^{14} \mathrm{C}$ at this location before 1950 . 


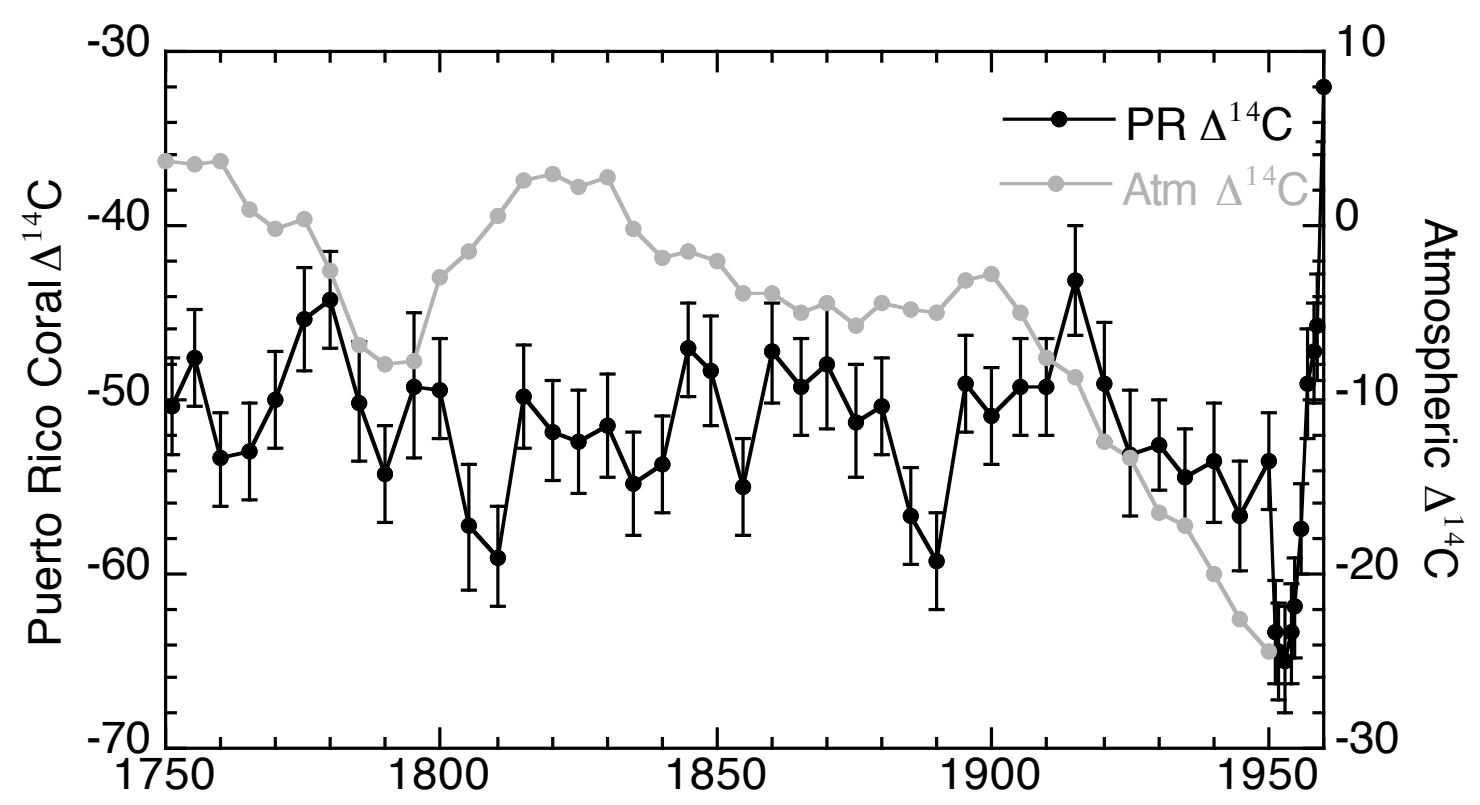

Figure 3: Puerto Rico coral $\Delta^{14} \mathrm{C}$ (black circles) and atmospheric $\Delta{ }^{14} \mathrm{C}$ (grey circles) from tree ring records (Reimer et al. 2004) spanning 1751 to 1960. Annual samples are reported every $5^{\text {th }}$ year until 1950 , when values are reported for each year. Large and relatively rapid variations occur in the ocean that cannot be explained from atmospheric forcing, indicating that advection and/or mixing are driving most of the coral $\Delta{ }^{14} \mathrm{C}$ variability. 


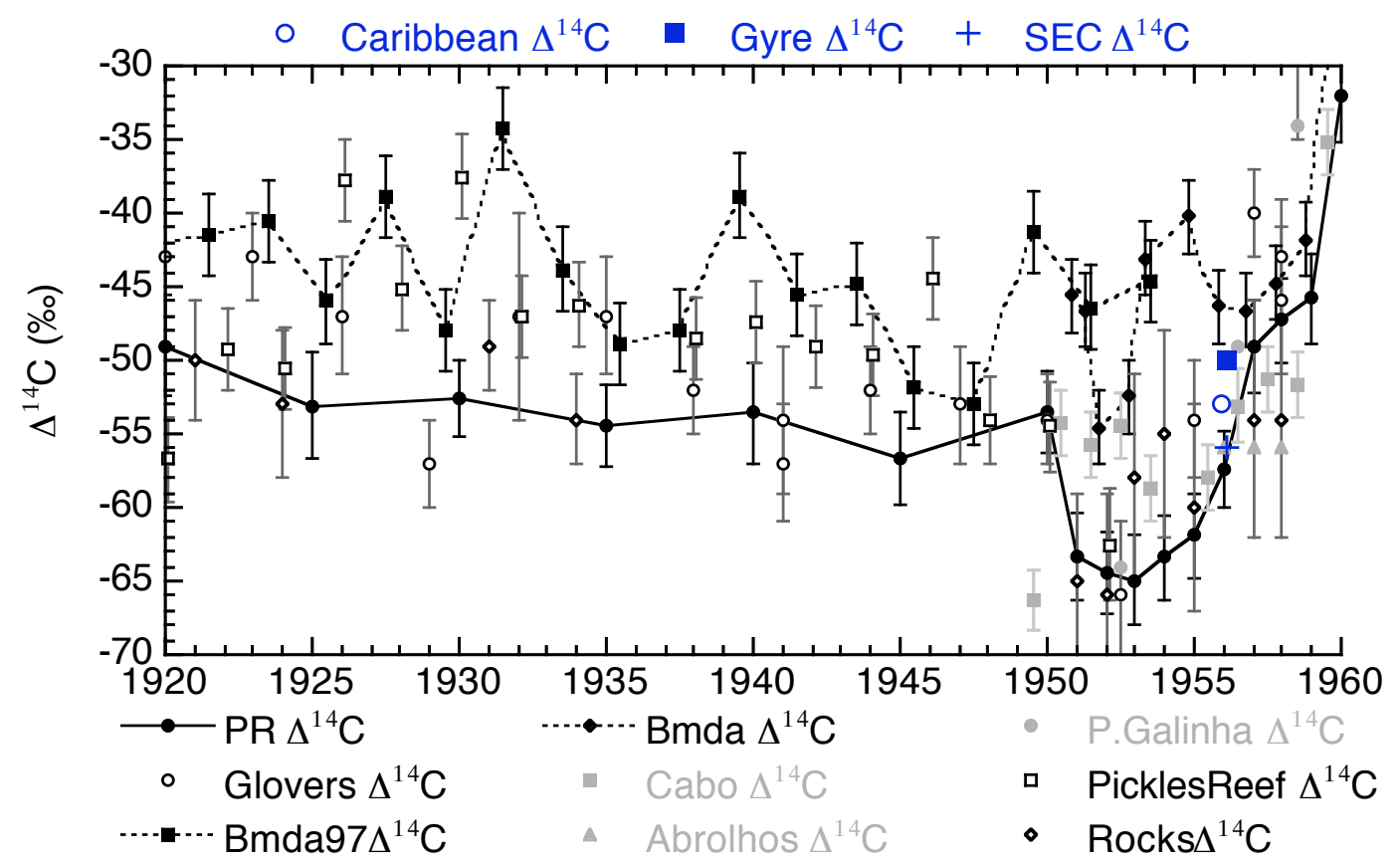

Figure 4: Coral $\Delta^{14} \mathrm{C}$ records from various sites around the western Atlantic capture a strong depletion between 1950 and 1953 in 5 different corals (Glovers Reef, Belize; Puerto Rico; Punto de Galinha, Brazil; Pickles Reef, Florida Keys; The Rocks, Florida Keys). Symbols are the same as in Figure 2, with the addition of blue symbols representing average seawater $\Delta^{14} \mathrm{C}$ measurements from three different water masses between 1955 and 1956 (Broecker and Olson 1961). Error bars represent analytical error. 


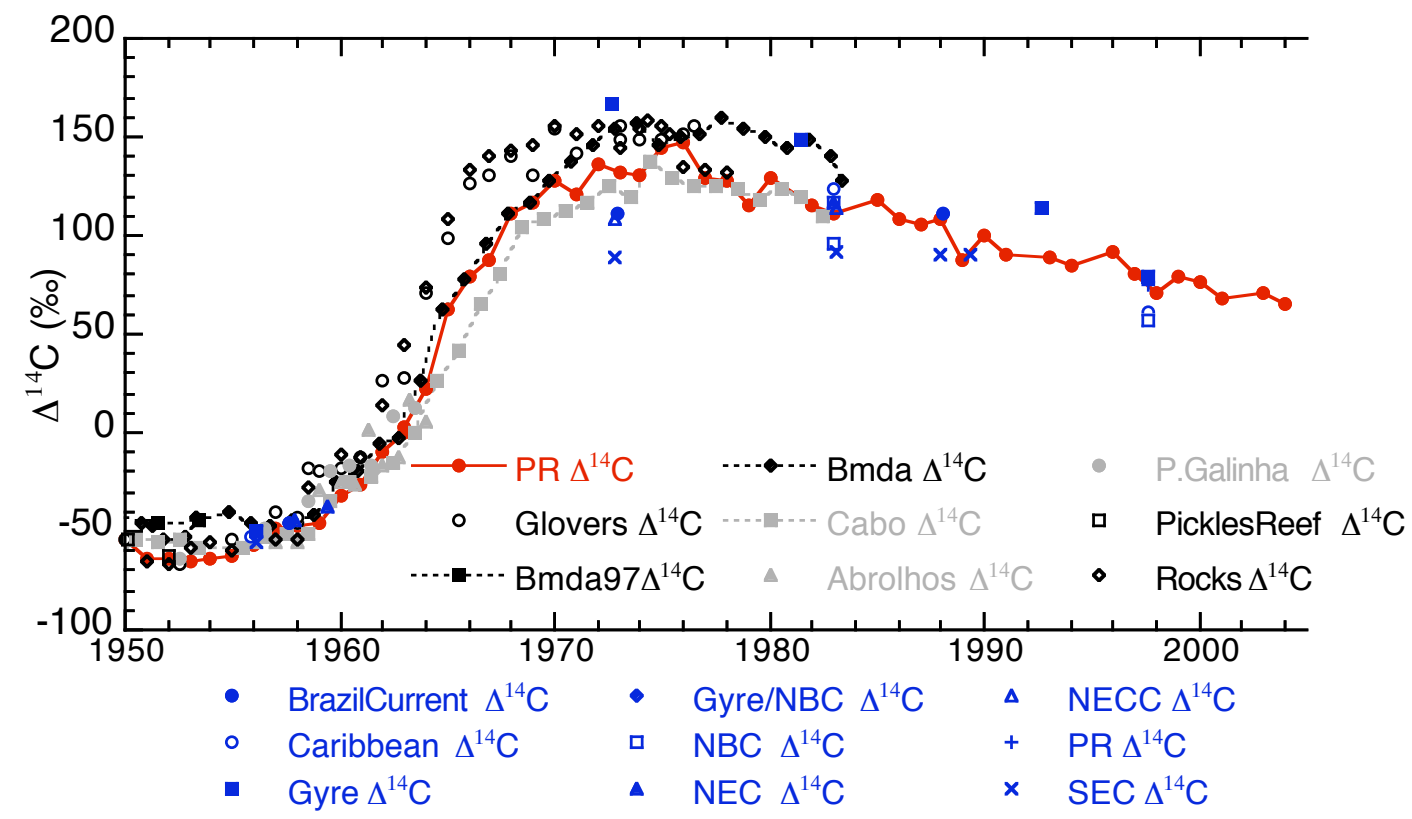

Figure 5: Post-bomb radiocarbon records from corals and seawater measurements of various water masses as determined by the sampling location (Ostlund and Grall 1987). Coral symbols are the same as in Figure 2. The data were binned into water masses according to the sampling location and the location of currents as depicted in Figure 1. 


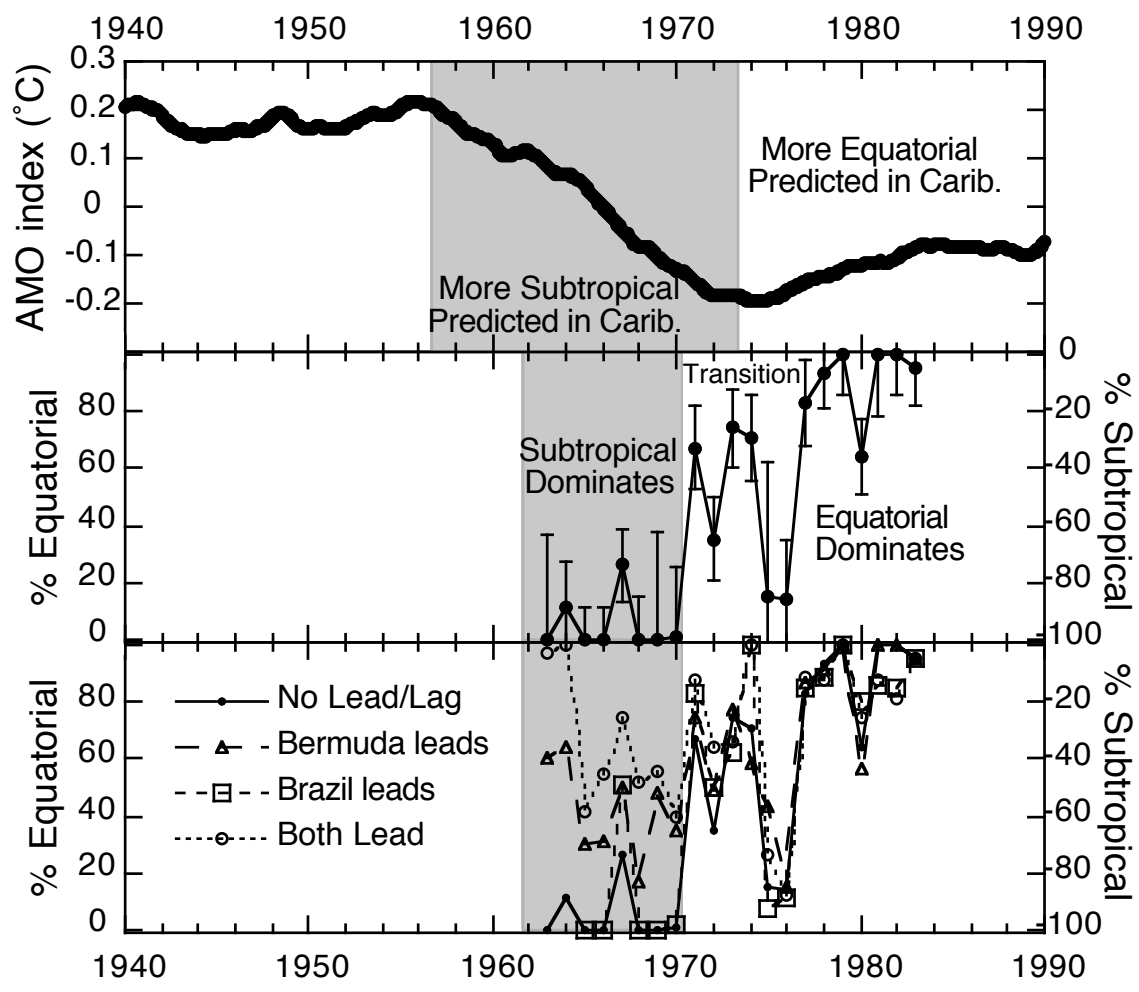

Figure 6: Predictions of a mixing model describe the sources of water bathing southwestern Puerto Rico using the Cabo coral $\Delta^{14} \mathrm{C}$ as the equatorial end member and the Bermuda coral $\Delta^{14} \mathrm{C}$ as the subtropical end member (middle panel). Error bars represent analytical error propagated through the mixing model calculation. The same mixing model with Bermuda and/or Brazil leading the Puerto Rico record by one year shows that the model is most sensitive to lead/lag relationships when $\Delta^{14} \mathrm{C}$ is changing most rapidly in the corals (lower panel). Coral radiocarbon data indicate a stronger influence of subtropical waters before 1971, and equatorial waters dominate the signal after 1976. The shift in coral $\Delta^{14} \mathrm{C}$ occurs just after a transition in the AMO (upper panel, Enfield et al. 2001) and is coincident with an increase in northern hemisphere trade wind strength, indicating that Ekman transport may play a role in the delivery of water into the Northern Caribbean. 


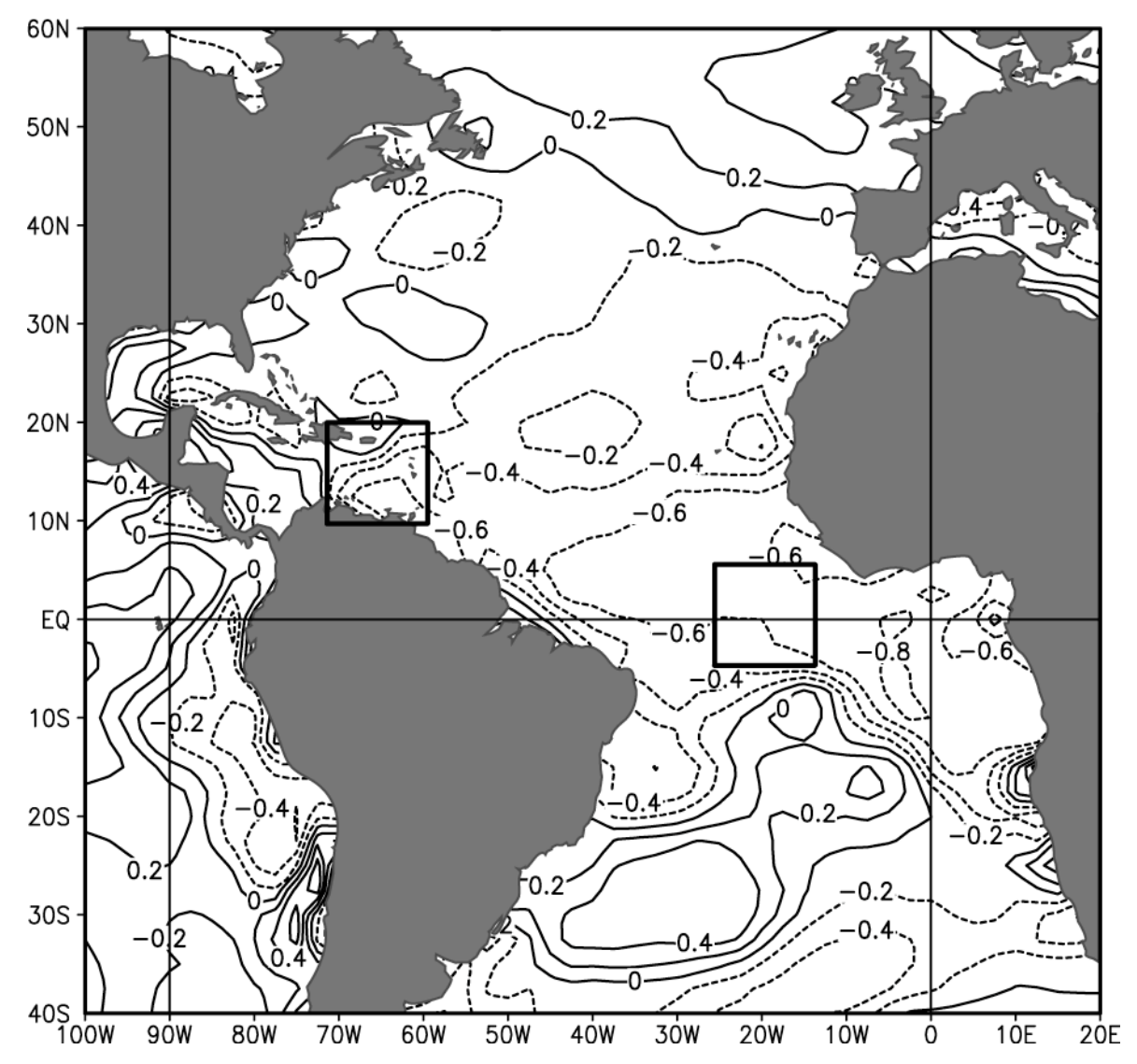

Figure 7: Spatial correlation between NCEP/NCAR reanalysis zonal wind velocity $(\mathrm{m} / \mathrm{s})$ and the coral-derived mixing model between 1963 and 1983, indicating that the observed changes in $\Delta^{14} \mathrm{C}$ at Puerto Rico are strongly correlated to the trade winds over a wide region of the tropical Atlantic. Negative contours are dashed lines, positive contours are solid lines, and the contour interval is 0.2 . The zonal component of the winds from each of the two regions indicated by boxes are shown in Figure 8. 


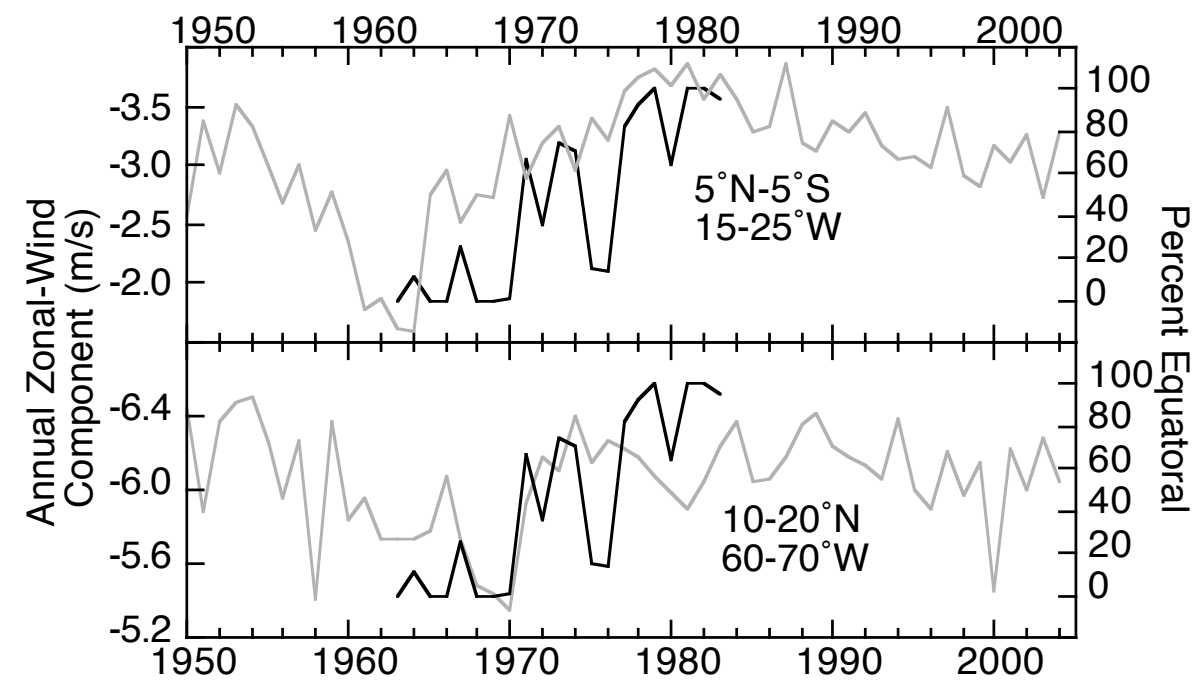

Figure 8: Time series of annual zonal wind velocity averaged over the boxed areas in Figure 7 and the results of the mixing model demonstrate that the trade winds were stronger during the latter portion of the study period. The data are not inconsistent with Ekman transport control on the amount of low $\Delta^{14} \mathrm{C}$ waters affecting Puerto Rico. Longer coral time series from key locations are needed to further substantiate the connection between wind speed and coral $\Delta^{14} \mathrm{C}$ proposed in this study. 